\title{
Mewujudkan Good Governance Badan Publik Negaradi Daerah Istimewa Yogyakarta Melalui Keterbukaan Informasi Publik
}

\section{Bringing the Good Governance of State Public Institution into Reality in Daerah Istimewa Yogyakarta through Public Information Transparency}

\author{
Dewi Amanatun Suryani \\ Fakultas Ekonomi, Ilmu Sosial dan Humaniora Universitas Aisyiyah Yogyakarta
}

\begin{abstract}
Abtraks
Semenjak diterbitkannya Undang-Undang No. 14 Tahun 2008 tentang Keterbukaan Informasi Publik (UU KIP) sebagai payung hukum perlindungan hak asasi manusia sebagaimana diatur dalam Pasal 28 F maka setiap warga negara memiliki hak atas akses informasi. Tujuan dari UU KIP diantaranya meningkatkan partisipasi masyarakat dalam proses perencanan pembangunan dan wujud tatakelola Badan Publik yang transparan dan akuntabel serta adanya pengawasan dari masyarakat dalam proses penyelenggaran negara yang baik. Badan Publik Negara di DIY memiliki kewajiban untuk mematuhi UU KIP dengan menyediakan, mengumumkan, dan melayani informasi. Penelitian ini melakukan penilaian terhadap pelaksanaan UU KIP pada Badan Publik Negara di DIY terhadap ketiga hal di atas melalui 3 (tiga) tahap penilaian yaitu Self Assessment Questionare (SAQ), Peninjauan Website, dan Kunjungan ke Badan Publik. Hasil penelitian menunjukkan bahwa komitmen Badan Publik Negara dalam mematuhi UU KIP masih rendah sehingga upaya mendorong budaya keterbukaan informasi pada Badan Publik perlu ditingkatkan. Hal-hal yang perlu mendapat perhatian dalam mewujudkan Keterbukaan Informasi adalah adanya PPID, pengembangan sistem informasi yang memberikan kemudahan layanan informasi yang cepat, biaya ringan, dan dengan bahasa yang mudah dipahami. Serta pengelolaan informasi yang akurat dan obyektif.
\end{abstract}

Kata kunci: Good governance, Keterbukaan, Informasi Publik, Badan Publik, Daerah Istimewa Yogyakarta

\begin{abstract}
Since the release of Law Number 14 of 2008 about Public Information Transparency (UU KIP) as legal foundation of the human right protection as governed in Article $28 \mathrm{~F}$, every citizen has the right to accessing information. The objectives of (UU KIP) are, among others, to improve the public participation in development planning process and the form of transparent and accountable Public Institution Good Governance, and the public's supervision over the good governance. The State Public Institutions in DIY are obliged to comply with UU KIP by providing, announcing, and serving information. This research studied the implementation of UUKIP in State Public Institutions in DIY regarding the three points above using the 3 (three) assessment stages: Self Assessment Questionnaire (SAQ), Website Review, and Visit to Public Institutions. The result of research showed that the State Public Institution's commitment to complying with UU KIP is still low so that the attempt of
\end{abstract}


encouraging the information transparency culture in Public Institutions can be improved. The factors that should be considered in realizing the Information Transparency were PPID, information system development providing some facilitation such as quick information service, low cost, and understandable language, and accurate and objective information management.

Keywords: Good Governance, Transparency, Public Information, Public Institution, Daerah Istimewa Yogyakarta

\section{Pendahuluan}

Reformasi tata negara yang berlangsung di Indonesia berpengaruh pada proses perubahan layanan publik. Jika dahulu penyelenggara Negara berorientasi pada pemangku kekuasaan maka sekarang pelayanan lebih diutamakan pada publik. Seiring dengan hal tersebut, diterbitkanlah paying hukum untuk menjamin hak dasar masyarakat terpenuhi seperti UU No. 14 Tahun 2008 tentang Keterbukaan Informasi Publik (UU KIP). Maksud diterbitkannya UU ini adalah mendorong terjadinya reformasi penyelenggaraan pemerintahan ke arah yang lebih transparan, akuntabel, partisipatif, efektif, dan efisien, serta sesuai dengan aturan hukum yang ada dan kebijakan pemerintah akan makin mudah diakses dan diawasi publik.

Dalam Pasal 3 UU KIP, tujuan keterbukaan informasi diantaranya sebagai berikut: (1) Menjamin hak warga negara untuk mengetahui rencana pembuatan kebijakan publik, program kebijakan publik, dan proses pengambilan keputusan publik, serta alasan pengambilan suatu keputusan publik; (2) Mendorong partisipasi masyarakat dalam proses pengambilan kebijakan publik; (3) Meningkatkan peran aktif masyarakat dalam pengambilan kebijakan publik dan pengelolaan Badan Publik yang baik; (4)
Mewujudkan penyelenggaraan negara yang baik, yaitu yang transparan, efektif dan efisien, akuntabel, serta dapat dipertanggungjawabkan; (5) Mengetahui alasan kebijakan publik yang mempengaruhi hajat hidup orang banya; (6) Mengembangkan ilmu pengetahuan dan mencerdaskan kehidupan bangsa; dan/atau (7) Meningkatkan pengelolaan dan pelayanan informasi di lingkungan Badan Publik untuk menghasilkan layanan informasi yang berkualitas.Pasal tersebut memberikan mandat bagi Badan Publik untuk menyediakan akses informasi dalam rangka mendorong dan meningkatkan partisipasi publik agar terlibat dalam seluruh proses pengambilan kebijakan publik serta adanya pengawasan masyarakat dan mewujudkan tata kelola penyelenggaraan negara yang baik.

Kelahiran UU KIP merupakan bagian dari upaya mewujudkan good governance (kepemerintahan yang baik) yang didalamnya mengandung unsur transparansi, partisipasi, dan akuntabilitas. Dinamika sosial dan politik pada tahun 1998 menjadi tonggak bagi pembahasan rancangan Undang-Undang yang menjamin hak atas akses informasi. Perubahan nama dari RUU Kebebasan Mengakses Informai Publik(RUU KMIP) menjadi RUU Keterbukaan Informasi Publik (RUU KIP). RUU KIP bukan 
berasal dari inisiatif pemerintah maupun DPR akan tetapi atas usulan kalangan aktivis prodemokrasi, jurnalis, intelektual, aktivis kampus,dan sebagian anggota parlemen yang berkeinginan mewujudkan keterbukaan informasi di Indonesia dengan mendorong dilahirkannya undang-undang seperti halnya fredom of information act di beberapa engara lain seperti Jepang, India, Nepal, dan Thailand untuk kawasan Asia (Abdulhamid Dipopramono, 2016).

Tantangan yang dihadapi dalam pembahasan UU KIP berasal dari pemerintah yang pada saat bersamaan sedang membahas RUU Rahasia Negara dan RUU Intelejen. Dua RUU ini memiliki semangat yang berlawanan dengan Keterbukaan Informasi. Paradigma RUU KMIP adalah keterbukaan sedangkan paradigma RUU Rahasia Negara dan RUU Intelejen adalah ketertutupan. Termasuk kategori Badan Publik yang awalnya hanya Badan Publik Negara kemudian meluas pada organisasi non pemerintah yang menerima sumbangan dari dalam maupun luar negeri.

Terbitnya UU KIP merupakan payung hukum atas hak akses informasi sebagaimana tercantum pada Pasal $28 \mathrm{~F}$ Amandemen Kedua UUD 1945, bahwa setiap orang berhak untuk berkomunikasi dan memperoleh informasi untuk mengembangkan pribadi dan lingkungan sosialnya, serta berhak untuk mencari, memperoleh, memiliki, dan menyimpan informasi dengan menggunakan segala jenis saluran yang tersedia. Pasal ini merupakan kelanjutan dari UndangUndang Nomor 28 Tahun 1999 tentang Penyelenggaraan Negara yang Bersih dan Bebas Korupsi, Kolusi, dan Nepotisme.
Harapan dari adanya UU KIP adalah terbangunnya kultur birokrasi yang transparan dan akuntabel.

Latar belakang UU KIP juga merujuk Pasal 19 ayat (2) Undang-Undang Nomor 12 Tahun 2005 tentang Kovenan Internasional tentang Hak Sipil dan Politik yang berbunyi "Setiap orang berhak untuk menyatakan mendapat/mengungkapkan diri, dalam hal ini termasuk kebebasan mencari, menerima, dan memberikan informasi/keterangan dan segala macam gagasan tanpa memperhatikan pembatasanpembatasan, baik secara lisan maupun tulisan atau tercetak, dalam bentuk seni atau sarana lain menurut pilihannya sendiri." Pengesahan UU KIP mengakhiri perjalanan panjang pembahasan RUU yang diinisiasi sejak tahun 2000. UU KIP disahkan tahun 2008 dan mulai diberlakukan bulan April 2010, untuk memberi kesempatan kepada Badan Publik dalam mengimplementasikan UU KIP.

Diterbitkannya UU KIP telah menempatkan Indonesia sebagai negara kelima di Asia, dan ke 76 di dunia yang secara resmi mengadopsi prinsip-prinsip keterbukaan informasi. UU KIP secara komprehensi telah mengatur kewajiban badan/pejabat publik untuk memberikan informasi, dokumen dan data diintegrasikan sebagai bagian inheren dari fungsi birokrasi pemerintahan, diperkuat dengan sanksi-sanksi yang tegas bagi pelanggarannya. UU KIP juga mengatur klasifikasi informasi sedemikian rupa sehingga secara teoritis memberikan kepastian hukum tentang informasiinformasi apa saja yang wajib dibuka kepada publik dan informasi apa saja yang 
bisa dikecualikan dalam periode tertentu (Agus Sudibyo, 2012)

Delapan tahun sejak UU KIP diterbitkan, implementasi UU KIP di DIYbelum menggembirakan. Sejak ajang penghargaan Keterbukaan Informasi yang diselenggarakan oleh Komisi Informasi Pusat pada Tahun 2014, DIY hanya menempati urutan ke 6. Tahun 2015 berada di peringkat ke- 10, dan tahun 2016 tidak lagi masuk dalam 10 besar peringkat terbaik se- Indonesia. Meskipun ajang penghargaan bukan satu-satunya indikator keberhasilan suatu daerah namun prestasi DIY yang makin terpuruk menjadi masalah menarik untuk diketahui ditengah berbagai prestasi yang telah diraih dan mendapat penghargaan WTP sebanyak 6 kali. Penelitian ini melihat bagaimana implementasi UU KIP dilaksanakan oleh Badan Publik Negara baik eksekutif, legislatif maupun yudikatif termasuk badan publik vertikal.

\section{Metode Penelitian}

Penelitian ini berangkat dari hasil monitoring dan evaluasi (monev) yang dilakukan oleh Komisi Informasi DIY terhadap Badan Publik Negara meliputi Lembaga Eksekutif, Legislatif, Yudikatif, yang terbagimenjadienamkategori dalam mengimplementasikan UU KIP. Hasil monev tersebut kemudian diperingkat dengan kategori sebagai berikut :

1. Kategori SKPD Provinsi (3 Terbaik);

2. Kategori Instansi Vertikal (3 Terbaik);

3. Kategori Lembaga Legislatif (3 Terbaik);

4. Kategori Lembaga Yudikatif
(3 Terbaik);

\section{Kategori SKPD Kabupaten/Kota (5} Terbaik); dan

6. Kategori Kecamatan (3 Terbaik);

Monev ini mencermati bagaimana badan publikmenyediakan, mengumumkan, dan melayani informasi sebagaimana termaktub pada pasal 9, 10, dan $11 \mathrm{UU}$ KIP dan Peraturan Komisi Informasi No 1 Tahun 2010 tentang Standar Layanan Informasi Publik (Perki SLIP). Pelaksanaanya dilakukan melalui 2 tahapan yaitu pertama, penyebaran Kuesioner Penilaian Mandiri (Self Assessment Questioner) ke seluruh Badan Publik. Yakni penilaian yang dilakukan secara mandiri oleh Badan Publik dengan mengisikuesioner. Selanjutnya, seluruh badan publik yang mengembalikan kuesioner tersebut kemudian dilihat dan dicocokkan dengan bukti data dan informasi yang terdapat pada website masing-masing badan publik (Verifikasi Website) dengan bobot masing-masing penilaian $40 \%$ dan $60 \%$. Tahap Kedua, Visitasi ke sejumlah badan public dengan jumlah 2 kali lipat dari Badan Publik yang masuk dalam nominasi dengan bobot tertinggi sesuai urutan untuk masuk dalam peringkat terbaik berdasarkan penilaian tahap satu. Visitasi dilakukan dengan wawancara dan pembuktian secara langsung dokumen-dokumen atau informasi dalam berbagai format/kemasan berdasarkan keterangan tertulis dalam SAQ.

Penyebaran Kuesioner Penilaian Mandiri (Self Assessment Questioner) oleh KID DIY sebanyak 333 (tiga ratus tiga puluh tiga), sedang badan publik yang 
mengembalikan berjumlah 226 (dua ratus duapuluhenam) atau sekitar $68 \%$ dari keseluruhan responden yang diminta mengisi kuesioner dengan rincian sebagai berikut:

\begin{tabular}{|c|l|r|r|}
\hline No & $\begin{array}{l}\text { Kategori } \\
\text { Badan } \\
\text { Publik }\end{array}$ & Dikirim & Diterima \\
\hline 1 & $\begin{array}{l}\text { SKPD } \\
\text { Provinsi }\end{array}$ & $\begin{array}{l}\text { SKPD } \\
\text { Kabupaten } \\
\text { Kota dan } \\
\text { Kecamatan }\end{array}$ & 243 \\
\hline 3 & $\begin{array}{l}\text { Instansi } \\
\text { Vertikal }\end{array}$ & 37 & $110+56$ \\
\hline 4 & Legislatif & 6 & 27 \\
\hline 5 & Yudikatif & 19 & 15 \\
\hline 6 & $\begin{array}{l}\text { PPID } \\
\text { Utama }\end{array}$ & 6 & 3 \\
\hline & TOTAL & $\mathbf{3 3 3}$ & $\mathbf{2 2 6}$ \\
\hline
\end{tabular}

Sumber: Data KID DIY 2016

Kuesioner yang dikirimke Badan Publik terdiri atas 3 Variabel utama yakni; 1. Mengumumkan (40\%), 2. Menyediakan (30\%), dan 3. Melayani (30\%), masingmasing Variabel memiliki beberapa Indikator dan Sub Indikator. Masingmasing Indikator dan sub indikator di setiap kategori memiliki bobot nilai yang berbeda. Jumlah keseluruhan masingmasing variabel adalah $100 \%$. Bobot paling tinggi pada variable mengumumkan adalah laporan keuangan sebesar $40 \%$, kemudian pengadaan barang dan jasa mempunyai bobot masing-masing $10 \%$. Program kerja, kinerja badan publik, peraturan dan keputusan badan public masing-masing memiliki bobot $7 \%$. Sedangkan profil, laporan akses informasi publik, tata cara pengaduan penyalahgunaan wewenang yang dilakukan pejabat badan publik, prosedur peringatan dini dan evakuasi keadaan darurat, informasi yang mengancam hajat hidup orang banyak dan ketertiban umum diberi bobot masing-masing $5 \%$, dan tata cara memperoleh informasi publik masingmasing diberi bobot 4\%. Variabel menyediakan terdiri dari: dokumen pendukung peraturan badan publik dengan bobot 9\%; DIP (Daftar Informasi Publik), dokumen tata kelola badan publik (pengelolaan organisasi, administrasi, kepegawaian, keuangan), dokumen pendukung surat-surat perjanjian dengan pihak ketiga, jumlah, jenis dan respon terhadap laporan yang diadukan masyarakat serta laporan penindakannya masing-masing diberi bobot $8 \%$; suratsurat perjanjian dengan pihak ketiga, surat menyurat pimpinan atau pejabat dalam rangka tupoksi, laporan layanan perizinan yang diberikan masing-masing dengan bobot $6 \%$; renstra dan renja badan publik, daftar kegiatan pelayanan informasi publik, izin yang diberikan beserta dokumen pendukungnya masing-masing berbobot 5\%; SOP pelayanan informasi publik, data inventaris, agenda kerja pimpinan satuan kerja, dan syarat-syarat perizinan masingmasing berbobot 4\%. Variabel melayani mulai dari bobot tertinggi yaitu mengembangkan system informasi (keterpaduan tata kelola penyediaan informasi publik) sebesar $15 \%$, tersedianya ruang khusus pelayanan, respon terhadap permohonan informasi publik, respon terhadap keberatan permohonan informasi publik, laporan layanan informasi public ke Komisi Informasi masing-masing berbobot $10 \%$, pelayanan melalui suratmenyurat elektronik, layanan daring 
(website, media sosial) masing-masing berbobot $6 \%$; SOP standar pelayan informasi publik, tersedianya meja informasi, tersedianya petugas informasi, tersedianya papan pengumuman, layanan telpon, SMS, Fax masing-masing berbobot $5 \%$; dan layanan melalui surat menyurat non elektronik dan layanan tatap muka masing-masing sebesar $4 \%$.

Kajian terhadap hasil monev ini merupakan bagian dari analisis implementasi kebijakan publik, sebagaimana disampaikan Merilee S. Grindle dalam Pratikno (2012) bahwa analisis implementasi kebijakan ada dua aspek penting yang diperhatikan, yaitu: Pertama, isi kebijakan. Isi kebijakan berpengaruh bagi implementasi karena menentukan ha-hal apa saja yang akan diimplementasikan serta siapa yang akan melakukannya. Kedua, konteks kebijakan. Kondisi sosial-politik serta office politics dalam tubuh birokrasi akan menentukan bagaimana kebijakan akan diimplementasikan. Dengan demikian hasil kajian ini menyoroti bagaimana kinerja badan publik dalam mengimplementasikan UU KIP melalui keberadaan PPID.

\section{Implementasi Keterbukaan Informasi di DIY}

Respon Pemerintah Daerah DIY dalam menyikapi gelombang reformasi birokrasi adalah sebuah pekerjaan yang tidak mudah. Idealisasi Pemerintah Provinsi DIY yang berbasis budaya adiluhung dengan simbol-simbol mitos yang sakral harus berhadapan dengan tuntutan percepatan reformasi yang seringkali lepas dari budaya dan tradisi Provinsi DIY. Dua hal yang berbeda dalam satu rumusan ideal tampaknya membutuhkan cara pandang yang lebih cermat. Jika dilihat lebih jauh, dua hal itu tampak kontradiktif. Satu sisi budaya birokrasi masih berpijak pada sistem budaya adiluhung, tetapi sisi lain harus berhadapan dengan tuntutan percepatan transparansi, partisipasi, dan akuntabilitas. (Yuyun Purbokusumo et.al. 2006)

Reformasi dapat berlangsung dari Yogyakarta dikarenakan Yogyakarta sangat kondusif sebagai wilayah istimewa yang didukung oleh 2 (dua) faktor utama; pertama, pola kepimpinan yang mampu menjadi katalisator dan sekaligus sebagai "panutan" bagi terselenggaranya kinerja pemerintahan. Kedua, dukungan masyarakat yang plural dan tingkat heterogenitas yang cukup memberikan andil besar terutama dalam hal kemampuan membangun solidaritas bersama.Untuk mendukung keberhasilan reformasi birokrasi, Pemda DIY menerapkan program pembaruan pelayanan terpadu masyarakat. Program ini dimulai dengan pembaruan struktur Pemerintah Daerah DIY dari 'kaya struktur, miskin fungsi' menjadi 'kaya fungsi, miskin struktur'. Artinya birokrasi yang baru dimungkinkan adanya upaya perampingan struktur dengan penguatan kerjasama lintas fungsi (cross functions). Perubahan struktur tersebut diiikuti dengan serangkaian upaya meliputi: pembaharuan organisasi dan tatalaksana, pembaharuan manajemen SDM, reformasi hukum dan peraturan, reformasi sistem keuangan dan pengawasan, serta reformasi budaya dan nilai. Dalam konteks reformasi administrasi publik (Kristian Widya Wicaksono, 2014) dipahami dalam 
beberapa bentuk pendekatan, diantaranya perubahan organisasi, pengembangan kultur kerja yang berorientasi pada kepentingan publik dan pembenahan sistem yang terintegrasi yang memudahkan akses terhadap informasi, memperlancar komunikasi dan menyediakan pengetahuan yang relevan bagi pengambilan keputusan.

Demikian juga dengan diterbitkannya UU KIP, Daerah Istimewa Yogyakarta termasuk provinsi yang sangat responsif menyambut lahirnya UU KIP terutama pembentukan Komisi Informasi di tingkat provinsi. Setelah Pemerintah RI melantik 7 (tujuh) komisioner tingkat pusat pada Juni 2009, Pemprov DIY langsung melakukan upaya pembentukan Komisi Informasi meski di tengah seleksi komisioner, Jawa tengah dan Jawa Timur yang lebih dahulu dapat menyelesaikan seluruh tahapan prosesnya. Komisi Informasi merupakan lembaga mandiri yang berfungsi menjalankan UU KIP dan peraturan pelaksanaannya menetapkan petunjuk teknis standar layanan Informasi Publik dan menyelesaikan Sengketa Informasi Publik melalui Mediasi dan/atau Ajudikasi Nonlitgasi.

Selain membentuk Komisi Informasi, kewajiban Badan Publik (Pemda DIY) adalah membentuk PPID (Pejabat Pengelola Informasi dan Dokumentasi). PPID adalah pejabat yang bertanggung jawab dalam penyimpanan, pendokumentasian, penyediaan, dan/atau pelayanan informasi di Badan publik (pasal 1 angka 9 UU KIP). Semenjak peraturan mengenai Keterbukaan Informasi dan Permendagri 35 Tahun 2010 tentang Pedoman PPID di Lingkungan Kemendagri dan Pemerintah Daerah diterbitkan maka Pemda DIY telah menindaklanjuti dengan menetapkan SK Gub Nomor 338/KEP/2010 kemudian diubah dengan Keputusan Gubernur Nomor 302/KEP/2011 dan terakhir diubah dengan Keputusan Gubernur Nomor 124/KEP/2016 tentang PPID. Kebijakan ini merupakan upaya Pemerintah Daerah DIY mengusung semangat reformasi di tubuh birokrasi. Sebagai PPID utama adalah Dinas Kominfo sedangkan PPID pembantu adalah seluruh SKPD di lingkungan pemerintah daerah. Sedangkan di Kabupaten/ Kota PPID utama berada di Humas masing-masing. Untuk instansi vertikal dan lembaga Yudikatif, PPID dijabat oleh Bagian Humas.

Tugas dan tanggung jawab PPID sebagaimana tercantum pada pasal $14 \mathrm{PP}$ 61 Tahun 2010 tentang Pelaksanaan UU KIP adalah sebagai berikut :

1. penyediaan, penyimpanan, pendokumentasian, dan pengamanan informasi;

2. pelayanan informasi sesuai dengan aturan yang berlaku;

3. pelayanan Informasi Publik yang cepat, tepat, dan sederhana;

4. penetapan prosedur operasional penyebarluasan Informasi Publik

5. pengujianKonsekuensi;

6. pengklasifikasian Informasi dan/atau pengubahannya;

7. penetapan Informasi yang Dikecualikan yang telah habis Jangka Waktu Pengecualiannya sebagai Informasi Publik yang dapat diakses;dan

8. penetapan pertimbangan tertulis atas setiap kebijakan yang diambil untuk 
memenuhi hak setiap orang atas InformasiPublik

Berdasarkan tugas PPID termasuk pelaksanaan Perki 1/2010 sebagai pedoman standar layanan informasi inilah maka penilaian implementasi keterbukaan informasi dilakukan. Hasil penilaian tersebut menjadi tolok ukur tingkat keterbukaan di DIY. Perolehan peringkat yang diumumkan KID DIY berdasarkan penilaian melalui SAQ, Website dan Visitasi adalah sebagai berikut :

\begin{tabular}{|c|c|c|c|c|c|}
\hline \multirow[b]{2}{*}{$\begin{array}{l}\mathrm{K} \\
\mathrm{A} \\
\mathrm{T} \\
\mathrm{E} \\
\mathrm{G} \\
\mathrm{O} \\
\mathrm{R} \\
\mathrm{I}\end{array}$} & \multirow[b]{2}{*}{$\mathrm{BP}$} & \multicolumn{3}{|c|}{ VARIABEL } & \multirow[b]{2}{*}{$\begin{array}{c}\text { TO } \\
\text { TAL } \\
\\
\text { NI } \\
\text { LAI }\end{array}$} \\
\hline & & $\begin{array}{l}\text { SAQ } \\
20 \%\end{array}$ & $\begin{array}{l}\text { WEB } \\
\text { SITE } \\
40 \%\end{array}$ & $\begin{array}{c}\text { VISI } \\
\text { TAS } \\
\text { I } \\
\\
40 \%\end{array}$ & \\
\hline \multirow{3}{*}{$\begin{array}{l}\text { S } \\
\text { K } \\
\text { P } \\
\text { D } \\
\text { D } \\
\text { I } \\
Y\end{array}$} & $\begin{array}{l}\text { Dinkes } \\
\text { DIY }\end{array}$ & 19 & 22 & 35 & 76 \\
\hline & DPPKA & 10 & 24 & 33 & 67 \\
\hline & $\begin{array}{l}\text { DPUES } \\
\text { DM }\end{array}$ & 7 & 8 & 30 & 45 \\
\hline \multirow{5}{*}{$\begin{array}{l}\mathrm{S} \\
\mathrm{K} \\
\mathrm{P} \\
\mathrm{D} \\
\mathrm{K} \\
\mathrm{A} \\
\mathrm{B} \\
/ \\
\mathrm{K} \\
\mathrm{O} \\
\mathrm{T} \\
\mathrm{A}\end{array}$} & $\begin{array}{l}\text { DUKCA } \\
\text { PIL Btl }\end{array}$ & 16 & 15 & 32 & 63 \\
\hline & $\begin{array}{l}\text { Ktr Pasar } \\
\text { Btl }\end{array}$ & 12 & 20 & 29 & 61 \\
\hline & $\begin{array}{l}\text { Disprein } \\
\text { dag SImn }\end{array}$ & 16 & 7 & 36 & 59 \\
\hline & $\begin{array}{l}\text { Disbud } \\
\text { Slmn }\end{array}$ & 15 & 9 & 32 & 55 \\
\hline & $\begin{array}{l}\text { Bappeda } \\
\text { Slmn }\end{array}$ & 12 & 8 & 33 & 53 \\
\hline \multirow{3}{*}{$\begin{array}{l}\mathrm{K} \\
\mathrm{E} \\
\mathrm{C}\end{array}$} & $\begin{array}{l}\text { Depok } \\
\text { Slmn }\end{array}$ & 11 & 14 & 30 & 55 \\
\hline & $\begin{array}{l}\text { Girimul- } \\
\text { yo Kp }\end{array}$ & 12 & 4 & 26 & 42 \\
\hline & $\begin{array}{l}\text { Pakem } \\
\text { Slm }\end{array}$ & 11 & 2 & 24 & 37 \\
\hline
\end{tabular}

\begin{tabular}{|c|c|c|c|c|c|}
\hline $\begin{array}{l}\mathrm{V} \\
\mathrm{E}\end{array}$ & $\begin{array}{l}\text { BPKP } \\
\text { DIY }\end{array}$ & 9 & 27 & 34 & 70 \\
\hline $\begin{array}{l}\mathrm{T} \\
\mathrm{I}\end{array}$ & $\begin{array}{l}\text { KPU } \\
\text { DIY }\end{array}$ & 14 & 9 & 34 & 57 \\
\hline $\begin{array}{l}\mathrm{K} \\
\mathrm{A} \\
\mathrm{L}\end{array}$ & KPU KP & 11 & 6 & 33 & 50 \\
\hline $\begin{array}{l}\mathrm{Y} \\
\mathrm{U} \\
\mathrm{D}\end{array}$ & PA KP & 13 & 32 & 33 & 78 \\
\hline $\begin{array}{l}\mathrm{I} \\
\mathrm{K}\end{array}$ & PA Btl & 9 & 19 & 31 & 60 \\
\hline $\begin{array}{l}\mathrm{T} \\
\mathrm{I} \\
\mathrm{F}\end{array}$ & PN KP & 11 & 14 & 31 & 56 \\
\hline
\end{tabular}

Sumber : Data KID DIY 2016

Disamping hasil yang telah dipublikasikan tersebut, pengamatan secara langsung dari Badan Publik yang mendapat peringkat terbaik memang didukung sarana prasarana yang memberi kemudahan bagi publik untuk mengakses informasi. Website milik Dinas Kesehatan Provinsi DIY pada menu utama sudah memuat menu PPID demikian juga DPPKA DIY. Untuk kategori instansi vertikal, BPKP dan KPU juga telah memiliki menu PPID. Demikian juga lembaga yudikatif. Sedangkan Badan Publik yang mendapatkan nilai dibawah 60, rata-rata websitenya belum menempatkan menu PPID. Alasan kesulitan yang dikemukakan oleh Badan Publik untuk menerapkan UU KIP adalah terbatasanya SDM, anggaran, dan sarana prasarana.

\section{Kesimpulan}

Secara garis besar dapat disimpulkan bahwa penilaian terhadap pelaksanaan UU KIP di DIY belum mampu mendorong kesadaran Badan Publik untuk menjalankan UU KIP. Jumlah Kuesioner 
yang dikembalikan masih minim menandakan bahwa Badan Publik belum menganggap penting terhadap kinerja layanan informasi publik. Keberadaan PPID hanya sebatas formalitas memenuhi ketentuan Undang-undang namun pelaksanaan tugas belum sepenuhnya dilakukan seperti mengumumkan informasi tentang profil badan publik secara lengkap, ringkasan informasi tentang program dan/atau kegiatan yang sedang dijalankan, ringkasan laporan keuangan, ringkasan laporan akses informasi publik, informasi tentang hak dan tatacara memperoleh informasi publik. Badan publik juga belum sepenuhnya menyediakan informasi terutama mengenai naskah/dokumen peraturan/regulasi yang dibuat sendiri, kegiatan pelayanan informasi publik, data mengenai jumlah, jenis, dan gambaran umum pelanggaran yang ditemukan dalam pengawasan internal serta laporan penindakannya, dan standar pengumuman informasi dalam memberikan izin dan/atau melakukan perjanjian kerja dengan pihak lain yang kegiatannya berpotensi mengancam hajat hidup orang banyak dan ketertiban umum. Demikian pula dalam hal melayani permohonan informasi ternyata tidak semua Badan Publik menyediakan ruang khusus pelayanan informasi publik, meja informasi, petugas yang melayani informasi, dan membuat laporan layanan informasi ke Komisi Informasi.

Selain kesadaran yang rendah untuk menjalankan UU KIP, Badan Publik terutama PPID menganggap tugas ini hanya sebagai tambahan. Hal ini ditandai dari 333 (tiga ratus tiga puluh tiga)Badan Publik, peringkat terbaik hanya mendapatkan nilai 76. Jika dirata-rata nilai 50- 100 maka nilai yang diperoleh belum memuaskan (belum mencapi nilai 80). Sesungguhnya ketugasan PPID merupakan pekerjaan humas ataupun bagian data dan informasi. Melalui UU KIP terdapat pengarsipan dan pendokumentasian data kemudian diklasifikasikan menjadi informasi setiap saat, berkala, serta merta, dan dikecualikan. Selain itu terdapat pengelolaan informasi untuk diumumkan dan disediakan juga laporan layanan informasi.

Terkait dengan keterbatasan SDM, semenjak adanya moratorium pengadaan PNS memang terdapat kekurangan sumber daya yang dapat melakukan pekerjaan yang sesuai dengan kompetensi yang dimiliki sehingga pelatihan dan bimbingan teknis bagi PPID sangat diperlukan untuk meningkatkan pemahaman pengelolaan informasi dan kualitas layanan informasi yang lebih baik. Dukungan anggaran yang memadai juga diperlukan untuk meningkatkan pelayanan informasi seperti sarana prasarana dan berbagai media layanan yang memudahkan dan sesuai dengan kebutuhan pengguna informasi. Sikap mental PPID pembantu yang bertugas memberikan dukungan kepada PPID utama juga kurang dilaksanakan karena Eselon PPID utama dan PPID pembantu sama sehingga perintah dari PPID kurang diindahkan. Oleh karena ituatasan PPID (Sekretaris Daerah) memiliki peran penting dalam mengingatkan dan monitoring ketugasan PPID secara keseluruhan.Forum PPID sebagai media koordinasi antara PPID utama dan PPID pembantu turut membantu menyelesaikan permasalahan yang dihadapi masing-masing PPID dan langkah awal pencegahan terjadinya sengketa informasi. Dengan membuka akses publik 
terhadap informasi dapat mempercepat perwujudan pemerintahan yang baik (good governance) melalui transparansi, akuntabiltas, dan partisipasi masyarakat dalam mengakses informasi.

\section{Daftar Pustaka}

Agus Sudibyo, et.al. 2012. Bunga Rampai Kebebasan Informasi Milik Siapa? Jakarta: Ford Foundation

Dipopramono, Abdulhamid. 2016. Keterbukaan dan Sengketa Informasi Publik. Jakarta: Renebook

Pratikno, et.al. 2012. Kajian Implementasi Keterbukaan Informasi Dalam Pemerintahan Lokal Pasca UU No 14 Tahun 2008. Yogyakarta: Fisipol UGM dan TIFA

Widya Wicaksono, Kristian. 2014. Telaah Kritis Administasi dan Manajemen Sektor Publik di Indonesia. Yogyakarta: Gava Media

Yuyun Purbokusumo et.al. 2006. Reformasi Terpadu Pelayanan Publik, Yogyakarta: Kemitraan dan Pemprov DIY

Undang-Undang No. 14 Tahun 2008 tentang Keterbukaan Informasi Publik

Peraturan Pemerintah No. 61 Tahun 2010 tentang Pelaksanaan UU No. 14 Tahun 2008

Permendagri 35 Tahun 2010 Tentang PPID di Lingkungan Kemenetrian Dalam Negeri dan Pemerintah Daerah

Peraturan Komisi Informasi No. 1 Tahun 2010 tentang Standar Layanan Informasi Publik 